(3) Family Hadrosaurida. - Teeth in several rows, forming with use a tesselated grinding surface. Anterior vertebrx opisthocoelian. Genera: Hadrosaurus (Diconius ?), Agathaumas, Cionodon.

(IV.) Order Theropoda (BEAst-Foot).-Carnivorous. Premaxillary bones with teeth. Anterior nares at end of skull. Large antorbital opening. Vertebræ more or less hollow. Feet digitigrade; digits with prehensile claws. Pubes projecting downward, with distal ends co-ossified.

(I) Family Megalosaurida.-Anterior vertebræ convexo-concave ; remaining vertebrac bi-concave. Pubes slender. Astragalus with ascending process. Genera: Megalosaurus (Poikilopleuron), Allosaurus, Cœlosaurus, Creoszurus, Drvptosaurus (Lælops).

(2) Family Labrosaurida.-Lower jaws edentulous in front. Cervical and dorsal vertebræ convexo-concave. Pubes slender, with anterior margins united. Astragalus with ascending process. Genus : Labrosaurus.

(3) Family Zanclodontida. - Vertebra bi-concave. Pubes broad elongate plates, with anterior margins united. Astragalus without ascending process. Five digits in manus and pes. Genera : Zanclodon (?), Teratosaurus.

(4) Family Amphisaurida.-Vertebræ bi-concave. Pubes rod-like. Five digits in manus, and three in pes. Genera : Amphisaurus (Megadactylus ?), Bathygnathus (?), Clepsysaurus, Palæosaurus, Thecodontosaurus.

(a) Sub-order Cailuria.-(5) Family Coturida.-Vertebra and bones of skeleton pneumatic. Anterior cervicals convexoconcave; remaining vertebræ bi-concave. Cervical ribs coossified with vertebræ. Metatarsals very long and slender. Genus : Cœlurus.

(b) Sub-order Compsognatira.-(6) Family Compsognathida.-Cervical vertebræ convexo-concave; remaining vertebræ bi-concave. Three functional digits in manus and pes. Ischia with long symphisis on median line. Genus : Compsognathus.

(c) Sub-order Cerastosauria.-(7) Family Ceratosaurida. - Horn on skull. Cervical vertebræ plano-concave; remaining vertebræ bi-concave. Pubes slender. Pelvic bones co-ossified. Osseous dermal plates. Astragalus with ascending process. Metatarsals co-ossified. Genus : Ceratosaurus.

The four orders defined above, which the author first established for the reception of the American Jurassic Dinosaurs, appear to be all natural groups, well marked in general from each other. The European Dinosaurs from deposits of corresponding age fall readily into the same divisions, and, in some cases, admirably supplement the series indicated by the American forms. The more important remains from other formations in this country and in Europe, so far as their characters have been made out, may likewise be referred with certainty to the same orders.

The three orders of herbivorous Dinosaurs, although widely different in their typical forms, show indications of approximation in some of their aberrant genera. The Sauropoda for example, with Atlantosaurus and Brontosaurus, of gigantic size, for their most characteristic members, have in Morosaurus a branch leading towards the Stegosauria. The latter order, likewise, although its type genus represents in many respects the most strongly marked division of the Dinosaurs, has in Scelido. saurus a form with some features pointing strongly toward the Ornithopoda.

The carnivorous Dinosauria now best known may all be placed at present in a single order, and this is widely separated from those that include the herbivorous forms. The three suborders here defined include very aberrant forms, which show many points of resemblance to Mesozoic birds. Among the more fragmentary remains belonging to this order, this resemblance appears to be carried much farther.

The Amphis zurida and the Zanclodontida, the most generalised families of the Dinosauria, are known only from the Trias. The typical gencra, however, of all the orders and sub-orders, are Jurassic forms, and on these especially the present classification is based. The Hadrosauride are the only family confined to the Cretaceous. Above this formation there appears to be at present no satisfactory evidence of any Dinosauria.

The peculiar orders Hallopoda and Aëtosauria include carnivorous reptiles which are allied to the Dinosauria, but they differ from that group in some of its most characteristic features. In both Aëlosaurus and Hallopus the calcaneum is much produced backwards. In the former genus the entire limbs are crocodilian, and this is also true of the dermal covering. In both of these genera there are but two sacral vertebræ, but this may be the case in true Dinosaurs, especially from the Trias. Future discoveries will probably bring to light intermediate forms between these orders and the typical Dinosaurs. The Crocodilia have some some strong affinities with the Dinosauria, especially with those of the order Sazropoda. The extinct genus Belodon of the Triassic, for example, resembles Diplodocus, particularly in the large antorbital vacuities of the skull, the posterior position of the external nasal aperture, as well as in other features. The Rhynchocephala, represented by the genus Hatteria, have several important characters in common with the Dirosauria, and, as the former is evidently an ancient type, it is probable that a real affinity may exist between these two groups.

That birds are closely related to Dinosaurs there is no longer any question. In addition to the various characters which these groups have been known to share with each other, two more may be added in consequence of discoveries made during the past year. The genus Ceratosaurus, a carnivorous Dinosaur from the Jurassic of the Rocky Mountains, recently described by the author, has the pelvic bones co-ossified, as in all known birds, living and extinct, except Archreopteryx. The same reptile, moreover, has the metatarsal bones firmly united, as in all adult birds, with possibly the single exception of Archaopteryx, while all the known Dinosauria, except Ceratosaurus, have both the pelvic and the metatarsal bones separate. The exception in each case brings birds and reptiles near together at this point, and their close affinity is now a matter of demonstration.

\section{THE DANISH EXPEDITION IN GREENLAND}

$W^{E}$ have on previous occasions referred to the Expedition under Lieuts. Holm and Garde, which has for more than a year been engaged in exploring the east coast of Greenland, and we are now able to supplement this with an interesting report from Lieut. Holm, written in the spring, from the winter quarters of the Expedition, and received some time ago by sailing-vessel at Copenhagen.

The place where the Expedition wintered is called Namortalik, and lies on the east coast, about fifty miles, as the crow flies, from Cape Farewell. It is also called Björneorten (the "bear-haunt"), from the many bears in the neighbourhood. After an excursion lasting two months and a half during the summer of 1883, the Expedition returned in September to Namortalik, but the huts for wintering not being finished, they started for a week's further excursion to the Fredriksdalsfjord, between Namortalik and Cape Farewell.

It was not until the end of October that the Expedition could begin their regular scientific observations at the station, but after that date they were continued without interruption through the winter. As, however, the chief object of the Expedition was to explore the east coast in boats, the scientific observations have not been so rich as those, for instance, of the Danish International Expedition at Godthaab in 1882-83 (NATURE, vol. xxix. p. "337); but every effort was made to adhere as strictly as possible to the programme of the International Polar Commission. The meteorological observations were made every third hour from 8 p.m. to 8 a.m., and the magnetic observations every hour except at 3 and $4 \mathrm{a}, \mathrm{m}$. On the Ist and 5th of every month the magnetic instruments were read every fifth minute during eight hours and every twentieth second during one hour.

With reference to the climatological conditions of the east coast, we learn that the winter is very raw and severe, although it cannot be said to be of excessive duration. The pleasant, calm, frosty weather which is experienced in North Greenland seldom prevails on the east coast, but in its stead there are fre. quent and sudden changes and violent storms; there being, for instance, one day $20^{\circ} \mathrm{C}$. of frost, and the next several degrees of heat, while heavy rains and snows alternate. In consequence of these sudden changes it is impossible in East Greenland to employ the mode of locomotion so valuable in other parts, viz. the dog-sledge. The only means of conveyance here is by boat. If, therefore, the sea is frozen over for a time, the inhabitants remain where they are, and wait patiently until a higher temperature removes the obstacle. The ice never becomes firm enough to bear a man and sledge.

Up to January last the temperature had not fallen lower than $15^{\circ} .5$ C. - about Christmas-the glass generally standing between 
$4^{\circ}$ and $6^{\circ}$, and even on some days not lower than zero $\left(=32^{\circ} \mathrm{F}\right.$.); This was particularly the case whilst the north-east "Föhn" wind prevailed, to which East Greenland is indebted for its comparatively mild winters; but there are places where the ice lies firm throughont the winter. On December 5, during a "Föhn" wind, the thermometer rose to $+10^{\circ} \mathrm{C}$. Aftcr the beginning of the new year, however, the cold became more severe, and the "Fohn" winds less frequent.

Towards the end of January and in February the thermometer sometimes registered $20^{\circ} \mathrm{C}$. of frost, and on March 9 it fell to $-2 \mathrm{I}^{\circ} 5$, the lowest temperature registered during the winter.

Some interesting particulars are also given of the almost unknown district in which the Expedition wintered. The station Namortalik is described as situated on an island, and as having a population of 250 souls. The island, which bears the same name, is surrounded by several others, which, lying further out to sea, are visited during the spring by the natives, who catch seals and eider-ducks there. To the north the scenery of Greenland is seen in all its grandeur and beauty; wild mountains with lofty cones rising above the clouds. These are on the beautiful but almost unapproachable island of Sermerols. If the air be clear, and the weather calm and sunny, the little island lies so peacefully in the ocean that one feels tempted to climb the Iofty mountains; but when the storm hovers around the peaks, half hidden in drifting clouds, and the Polar Sea is a mass of foam, the giant forms of the mountains deter even the boldest. The mainland is rugged, like the island just mentioned; in fact, the whole southern portion of Greenland is a region of wild mountains, furrowed by tremendous ravines, and rising to a height of nearly 8000 feet, from which enormous glaciers descend to the sea. The landscape produces by its wildness and desolation very striking impressions.

There are thirty little turf-covered houses at Namortalik, including a bakery and a brewery. The so-called "Royal Commerce of Greenland," a Danish Company, has also a depot here. There is, besides, a Iutheran mission, a church, and a school attended by half-caste Greenlanders.

The Expedition has erected two observatories on the rocks, about 1000 fect from the dwelling-houses, but connected by telephore.

Close to Namortalik is the Tasermint Fjord, some fifty miles in length, one of the loveliest in South Greenland. On its shores the vegetation is very luxuriant in summer, and the heat and mosquitoes are so troublesome that one could imagine one's seif in the tropics. This fjord is of great importance to the Namortalik people, as its shores provide them with fucl, its streams and waters with salmon, seals, and herrings, and its mountain-slopes with ptarmigans, Polar hares, and foxes.

When the summer commenced, the Expedition intended to leave their quarters, and continue the exploration of the east coast; but there is at present no news of their achievements this summer. The programme is, however, to explore the east coast by sea and land as far north as possible, and to get into communication with the natives whenever opportunity offers, in which latter attempt nearly all previous Expeditions have been disappointed.

At the beginning of this winter one half of the Expedition was to return to Namortalik, while the second endeavoured to spend the winter as far north as possible. The Expedition will leave Grccnland in the autumn of next year.

\section{SCIENTIFIC SERIALS}

Fournal of Botany, August to November. - The most important article in the recent numbers of this magazine is Mr. Charles Bailcy's paper on the structure, \&c., of Naias sraminea, Delile, var. Delilei, Magnus, illustrated with four plates and many woodcuts. This interesting addition to the British flora-first found in 1883 in a canal in Lancashire-is a native of warmer climates, not being indigenous anywhere in Europe, and has probably been introduced with Egyptian cotton. Mr. Bailey gives an exhaustive account of the morphology of its various organs, and especially of its mode of fertilisation. The Naias belongs to a class of plants that may be called "protozoophilous," the pollen being carried to the stigma by aquatic animals of low organisation, in this instance by the currents caused by the rotating cilia of species of Vorticellidæ - Most of the other articles in these numbers are of more limited interest, being topographical papers on the flowering plants or cryptogams of particular districts, or descriptions of new or little-known species. -Additional instalments are also given of Mr. J. G. Baker's synopsis of the genus Selaginella, which is still uncompleted, the species now described amounting to $\mathrm{I} 8 \mathrm{o}$.

Nutvo Giornale Botanico Ilatiano, July to October.-The greater part of the space in the July number of this magazine is occupied by descriptive papers. The paper of most general interest is that by A. Piccone, on the algæ of the Red Sea. He shows that the algal flora of this sea shows much closer affinities to that of the Indian Ocean than of the Mediterranean. It is characterised by the small number of diatoms and of green algæ generally, by the entire absence of Laminariex, and, above all, by its extraordinary richness in species of Sarsassum, many of them endemic.-In the October number are a synopsis of the flora of Sicily, and a list of the "pronubi" or insect-fertilisers of flowering plants in Calabria and Piedmont; also a note by R. Pirotta, showing, from an examination of the oospores, the identity of Cystopus capparidis, parasitic on the caper, with Cystopus candudus, the common parasite of cruciferous plants.

\section{SOCIETIES AND ACADEMIES LONDON}

Linnean Society, November 6.-Sir J. Lubbock, Bart., President, in the chair. - A letter was read intimating that their late President, Mr. G. Bentham, had bequeathed in his will a legacy of $1000 l$. to the Society. - A notice of invitation for tive Fellows to attend the centenary (December 4) of the Royal Bohemian Society of Natural History in Prague was also read from the chair.-Mr. W. T. Thiselton Dyer exhibited the following plants and their products :-(I) Vaccinium arclostaphylus, from which the Trebizonde tea ("Thé-du-Bu-Dagh") is preparer at Amassia and Tokat. The tea has a pleasant odour, but a somewhat harsh taste when drunk. (2) Pueraria Thunbergiana, specimens of this Corean plant and of the cloth made from it. (3) Pachyrhyza sincnsis, with the native name of "Kopoo," a leguminous plant from the fibres of which the yellow and more expensive summer cloth is made.-Mr. Thos. Christy showed and made remarks on a specimen of Kola acuminata. Mr. R. A. Rolfe afterwards exhibited examples of British oak-galls produced by Cynipidean insects of the genus Neuroterus. These were the silk-button gall formed by $N$. numismatis, the globose gall produced by $N$. ostreus, the smooth-spangle gall formed by $N$. fumipennis, the scarce-spangle gall formed by $N$. lreviusculus, and the common spangle gall produced by $N$. lenticularis, as also a purple variety of the latter gall. He stated that the plan and details of the galls depend on the nature of the irritating fluid deposited by the insect; but on the other hand the different species of oak seem to have an influence in determining certain variations as to colour, and, it may be, general growth, of the galls.-Mr. Geo. Brook read a paper on the development of the Five-bearded Rockling (Molella mustela) in which the following points were enunciated :- (I) Whereas there is only one large oil globule in the normal egg of Motella, somelimes this is subdivided into from two to eight or even more but in these cases there is always an abnormal development which often results in the death of the embryo. In those that survive, the small oil globules always coalesce to form one large one before the embryo hatches. (2) In the further development of the newly-hatched embryo there is a cranial flexure produced which is analogous to that so characteristic of Elasmobranchs. This is caused by the rapid development of the dorsal portion of the head, while the ventral portion remains comparatively quiescent. Later, the ventral portion plays its part, and, with the development of the jaws the brain is pushed back to its normal position. (3) As in other pelagic Teleostean eggs, there is no circulation observable either in the embryo or in the vitellus up to the time of hatching, nor indeed for some days afterwards. (4) In Mo'ella the anal gut does not open on the ventral surface for at least a week after hatching. Rycler has shown the same to be the case with the cod-fish, so that the young Gadidee would not appear to be in a position to take solid food at nearly so early a period in their existence as is usual with Telcostcans. Mr. Brook also called attention to the influence of temperature on the rate of development of pelagic eggs, and suggested that, until we know the temperature at which the various observations are made on these forms, no true comparison can be established.-The next communication was on a collection of 